\title{
New trends in the development of the lithium metallurgy
}

\author{
V. K. Kulifeev, V. P. Tarasov, O.N. Krivolapova, V.V. Miklushevskiy \\ State Technological University "Moscow Institute of Steel and Alloys", \\ 4 Leninsky prospekt, 119991 Moscow, Russia \\ onfedosova@list.ru
}

The investigation results of the utilization of various-production lithium wastes in the sphere of aluminate synthesis, vacuum aluminothermic lithium production and development of aluminothermic reduction units have been generalized in the study. The flow charts for lithium-bearing waste processing with the production of ecologically clean products have been designed. It was demonstrated that lithium aluminates could be synthesized not only when processing wastes, but also out of marketable lithium and aluminum compounds and could serve as initial materials for the designed technology for the lithium production.

Lithium is one the most important metals of the state-of-the-art technology. Fields of its application are continuously extended. It is favored by its unique properties and considerable natural reserves in various fields and salt lake brine. The production of lithium continuously increases. Average annual rates of the increase since 1950 amount to $8.5 \%$ and during the past decade to $9.4 \%$. At the present time the world production of lithium is estimated as 16.2 thousand $t$ a year.

Lithium metal finds an application in the production of primary lithium current power supplies, lithium accumulators, in the production of synthetic rubber and thermoplastic elastomers, as well as in the production of unique properties- possessing Al-Mg-Li alloys.

Due to the development of the newest technology branches a $20-25 \%$ annual growth in the lithium consumption, for instance, in the production of LCCSs (lithium-bearing chemical current sources), is expected [1]. At the present time the lithium commercial production is based on the electrolytic production method. $\mathrm{LiCl}$ is an initial product. In order to lower the melting point, an equimolar $\mathrm{LiCl}-\mathrm{KCl}$ mixture is applied that provides the operation regime within the range of working temperatures of $420-430^{\circ} \mathrm{C}$ [2]. This process has significant disadvantages that include: application of the most expensive highly hygroscopic and corrosive lithium salt $(\mathrm{LiCl})$, necessity to neutralize escaping chlorine, necessity to utilize spent electrolyte and use of direct current. The necessity to apply alternative methods for obtaining lithium metal is now an urgent task. Metallothermic methods can be such alternative methods. In studies [3, 4] the lithium aluminothermic reduction out of its monoaluminate was tried. At $1,000-1,200^{\circ} \mathrm{C}$ and high vacuum a yield of pure metal over $90 \%$ could be obtained.

During past years we conducted extensive studies of the synthesis of lithium oxide compounds applicable in metallothermic processes of the lithium production and designed high-temperature reduction processes. Lithium aluminates were used that are sufficiently inert, non- volatile and have a high melting point.

The formation of three compounds was found out: lithium monoaluminate $\mathrm{LiAlO}_{2}$, lithium pentaaluminate $\mathrm{LiAl}_{5} \mathrm{O}_{8}$ and pentalithium aluminate $\mathrm{Li}_{5} \mathrm{AlO}_{4}$. Monoaluminate is formed upon heating equimolar mixture of $\mathrm{Li}_{2} \mathrm{CO}_{3}$ and gamma- $\mathrm{Al}_{2} \mathrm{O}_{3}$ at $600^{\circ} \mathrm{C}$. Above that temperature the process of the polymorphic transformation of alpha- $\mathrm{LiAlO}_{2}$ to beta- $\mathrm{LiAlO}_{2}$ begins. The 
beta- $\mathrm{LiAlO}_{2}$ rhombohedral cell has the following lattice parameters: $\mathrm{a}=2.801 \mathrm{~A}, \mathrm{c}=14.214$ A. The $\mathrm{LiAlO}_{2}$ density amounts to $3.401 \mathrm{~g} / \mathrm{cm}^{3}$. The gamma- $\mathrm{LiAlO}_{2}$ tetragonal phase is characterized by the following lattice parameters: $a=5.169 \mathrm{~A}, \mathrm{c}=6.268 \mathrm{~A}$. The $\mathrm{LiAlO}_{2}$ density is $2.615 \mathrm{~g} / \mathrm{cm}^{3}$ [5].

Upon polymorphic transformation of lithium monoaluminate, the aluminum coordination number in relation to oxygen changes from 6 to 4 [6].

In addition to well studied modifications of lithium monoaluminate, there exists the modification [7] that can be obtained by:

- sintering $\mathrm{LiOH}$ with $\mathrm{AL}_{2} \mathrm{O}_{3}$ at $500{ }^{\circ} \mathrm{C}$ for $120 \mathrm{~h}$;

- sintering lithium peroxide with aluminum nitride at $550^{\circ} \mathrm{C}$ and pressure of $220 \mathrm{MPa}$ for $11 \mathrm{~h}$ or sintering lithium peroxide with aluminum oxide at $370{ }^{\circ} \mathrm{C}$ and pressure of 1,800 $\mathrm{MPa}$ for $10 \mathrm{~h}[8]$.

At a temperature of $900^{\circ} \mathrm{C}$ the polymorphic transformation of beta- $\mathrm{LiAlO}_{2}$ to gamma $\mathrm{LiAlO}_{2}$ takes place [7]. According to [8], gamma-LiAlO 2 is crystallized in monoclinic syngony of lattice parameters $a=8.147 \mathrm{~A} ; \mathrm{b}=7.941 \mathrm{~A} ; \mathrm{c}=6.303 \mathrm{~A} ; \mathrm{d}=93.18 \mathrm{~A}$. The melting point of lithium monoaluminate is $1,700 \pm 15^{\circ} \mathrm{C}$ [9]. Lithium pentaaluminate $\mathrm{LiAl}_{5} \mathrm{O}_{8}$ melting at $1,950^{\circ} \mathrm{C}$ forms octahedral crystals and belongs to the spinel class.

Our studies in MISiS on the lithium subject were commenced with the investigation of the possibility to utilize lithium wastes [10,11]. Ecologically clean flow charts for processing wastes from the synthetic rubber and elastoplastic production, light alloy production, production of lithium chemical current power supplies, including discarded and civil- and military-purpose exhausted lithium cells and accumulators were designed.

We investigated these reactions and designed the technology for the pentalithium aluminate synthesis $[12,13]$. The technology provides for charge stage heating since the charge composition comprises a significant portion of low-melting component: lithium carbonate that upon dissociation forms with lithium oxide low-melting eutectic of a melting temperature of $710^{\circ} \mathrm{C}$ [3]. Samples with a $\mathrm{Li}_{5} \mathrm{AlO}_{4}$ phase content over $95 \%$ were obtained by this technology. There is no necessity to produce aluminates containing $100 \%$ of lithium monoaluminate phases or pentalithium aluminate to obtain lithium by the aluminothermic method that considerably simplifies the synthesis technology. Two reactions are used in the investigation basis for designing the aluminothermic technology for the lithium production:

$$
\begin{aligned}
& 3 \mathrm{LiAlO}_{2}+\mathrm{Al}=3 \mathrm{Li}+2 \mathrm{Al}_{2} \mathrm{O}_{3} \\
& 3 \mathrm{Li}_{5} \mathrm{AlO}_{4}+5 \mathrm{Al}=15 \mathrm{Li}+4 \mathrm{Al}_{2} \mathrm{O}_{3}
\end{aligned}
$$

The reaction thermodynamics, sequence of reaction (1) running according to the Baikov rule through obtaining $\mathrm{LiAlO}_{2}$, then $\mathrm{LiAl}_{5} \mathrm{O}_{8}$ and $\mathrm{Al}_{2} \mathrm{O}_{3}$ were investigated. It was found out that $\mathrm{LiAl}_{5} \mathrm{O}_{8}$ was the thermodynamically most stable phase of lithium aluminates. The temperature dependence of the lithium vapor pressure over the reduction charge was defined in the experimental plant:

$$
\operatorname{Lg} \mathrm{P}(\mathrm{Li})=-(11,980+60) / \mathrm{T}+10.15+0.06(\mathrm{~Pa})------
$$

In addition, thermodynamic characteristics of $\mathrm{LiAl}_{5} \mathrm{O}_{8}$ were defined $(\mathrm{H}=4,560.0+7.5 \mathrm{~kJ} / \mathrm{mol}$; $\mathrm{S}=176.4+1.35 \mathrm{~J} / \mathrm{mol}^{*}$ degree $)$, as well as design data for $\mathrm{C}_{\mathrm{p}}(\mathrm{a}=288.3 ; \mathrm{b}=60.0$ and $\mathrm{c}=8.4)$.

Aluminothermic lithium is comparable in quality with electrolytic one and even exceeds it, especially as regards difficult-to-sublimate impurities, for instance $\mathrm{Fe}, \mathrm{Mn}$, Si. We 
performed a cycle of studies for analyzing the original material impact onto the lithium quality and their cleaning of potassium and sodium [14]. It was shown that the principal contribution was made by alumo-containing materials such as aluminum oxide and hydroxide and lithium hydroxodialuminate. Lithium carbonate can be used directly or additionally cleaned up to an acceptable purity. The development of the aluminothermic method for lithium obtaining resulted in the necessity to design devices for the implementation of the technology under study. A series of devices for lithium aluminothermic production was designed in MISiS. The plants for obtaining calcium, magnesium, for calcium stripping out of copper-calcium alloy or magnesium out of titanium sponge were taken as a basis. These units are in operation under industrial conditions for a long time and the process parameters are close or identical to the lithium production parameters. The latest developments made in MISiS are related to the problems of improving the technology for the metallic lithium production in the SYNTHESIS-REDUCTION mode. In practice two processes run in the same charge and in the same unit. The process is performed in two stages. At the first stage at a temperature of $650-700^{\circ} \mathrm{C}$ and residual pressure of 10-50 Pa, lithium carbonate dissociates with the extraction of $\mathrm{CO}_{2}$, and the synthesis of $\mathrm{LiAlO}_{2}$ takes place for 4-5 hours. At the second stage, the synthesized lithium monoaluminate is reduced by aluminum powder with lithium monoaluminate reduction parameters.

The implementation of MISiS developments depends entirely on the economic situation in the Russia industry. Under the conditions of the started economic recovery $2-3.5 \%$ annual rates of the lithium consumption growth can be anticipated and in this case the demand can amount to 2,000-2,250 t by 2015 that complies with the present consumption in the USA and Japan.

1. Metal Bulletin, March 13. (1997)

2. Kulifeev V.K., Proceedings of higher schools, Non-ferrous metallurgy, No. 5 p.15-18 (1992).

3. Smirnov M. V. JIC, vol. XVI, p. 251-253

4. Fedorov T.F., Shamrai F.I. - In book: Vacuum application in metallurgy. M.: p.137-142 (1960).

5. Marezio M. and .Remeika J.P., J. of Chem. Phys. 44, N 8, p. 89- 91 (1978)

6. Kolesova V.A., Proceedings of USSR AS, CSD, No. 11, p. 2082-2084 (1962).Mining Magazine, v. 176, No. 254, p.2-11 (1997).

7. Albert K., Fisher, Inorganic Chemistry, 16, N 4, p. 71-73 (1977).

8. Chang C.H., Margrave J., J. Amer. Chem. Soc. 90, N 8, p. 2020-2027(1968)

9. Lejus A.M. Rev. Hautes Temperat. Refract. 1, N 1, c. $72-83$ (1961).

10. Kulifeev V.K., Tarasov V.P., Miklushevsky V.V., New trends in the development of lithium technology// Metal technology. 2003 No. 2, p. 9-13.

11. V.K. Kulifeev, V.V. Miklushevsky, V.P. Tarasov, O.N. Krivolapova, Development of technological processes for complex utilization of lithium chemical current sources. Collection of theses of the Russian-Chinese conference "Two-side scientific and educational cooperation of higher schools of Russia and universities of China in the sphere of the arrangement of the scientific and educational cooperation, preparation of scientific and pedagogical workers and training young specialists". Moscow, October 24-27, 2007, p. 28-31.

12. Kulifeev V.K., Tarasov V.P., Miklushevsky V.V., Proceedings of higher schools. Non-ferrous metallurgy, No. 6, p.20-24 (1991).

13. USSR A.C. No. 1622288 dated 01.6.1989.

14. Tarasov V.P., Orlov S.B., Suslov V.M., Theses of lectures on the state-of-the-art of developments and manufacture of lithium-based anode current sources. Theses of lectures at the VIII International conference "Basic problems of energy transformation in lithium, electrochemical systems", Yekaterinburg (2004). 
